\title{
The Effect of Aliskiren on Renal Cortical Ischemia/Reperfusion Injury in Albino Rats: A Histological and Immunohistochemical Study
} Original Article

\author{
Dalia Ibrahim Ismail and Alshaymaa Gamal Aboulkhair
}

Department of Histology, Faculty of Medicine, Cairo University, Cairo, Egypt

\begin{abstract}
Background: Ischemia/reperfusion injury (IRI) is a foremost reason for acute kidney injury, which is a common clinical complication having high morbidity rate and lacks effective therapy. Renin-angiotensin system (RAS) activation and angiotensin II level elevation are important risk factors in IRI. Aliskiren (ALS) is the first oral direct rennin inhibitor that blocks the first step in RAS and has been approved for treating hypertension.

Aim of work: Investigating whether ALS pretreatment protects the renal cortex of adult male albino rats subjected to IRI. Material and Methods: Thirty adult male albino rats were divided into 3 groups: group I (control group), group II (IRI group): were subjected to IRI procedure, group III (ALS group): rats were pretreated with aliskiren (ALS, $100 \mathrm{mg} / \mathrm{kg}$ ) twice orally $24 \mathrm{~h}$ and $1 \mathrm{~h}$ before IRI and left for $24 \mathrm{~h}$ of reperfusion before scarification. Blood samples were taken to estimate the levels of blood urea nitrogen (BUN), serum creatinine (SCr) and superoxide dismutase enzyme (SOD). Kidneys sections were stained with HandE and PAS stains and immunohistochemical staining against COX-2 and caspase-3. This was followed by morphometric and statistical analysis.

Results: IRI group showed deterioration in renal function tests with massive histological alterations in the Malpighian renal corpuscles and the convoluted tubules. There was significant decrease in optical density of PAS reaction, with significant increase in the mean area\% of COX-2 and caspase- 3 immunoexpression. ALS group showed significant improvement in renal function tests with preserved normal histology of the renal cortex. There was significant increase in the optical density of PAS reaction, with significant decrease in the mean area $\%$ of COX-2 and caspase- 3 immunoexpression.

Conclusion: A protective effect of ALS was detected in IRI-induced renal cortical damage in adult male albino rats. This was evidenced by laboratory results, histological and immunohistochemical evaluation.
\end{abstract}

Received: 19 March 2019, Accepted: 20 April 2019

Key Words: Apoptosis; inflammation; ischemia/reperfusion injury; oxidative stress.

Corresponding Author: Dalia Ibrahim Ismail, MD, Department of Histology, Faculty of Medicine, Cairo University, Cairo, Egypt, Tel.: +20 1005050870, E-mail: drdaliaibrahim@hotmail.com

ISSN: $1110-0559$, Vol. 42, No. 4

\section{INTRODUCTION}

Ischemia/reperfusion injury (IRI) refers to a pathological condition characterized by preliminary reduction in the blood supply to an organ followed by blood restoration with subsequent re-oxygenation. The reduction in blood flow leads to decreased oxygenation and delivery of nutrients, together with decreased removal of waste products $^{[1]}$. This is of particular importance in the kidneys, because of its high perfusion rate; the renal injury resulting from IRI does not improve but usually worsens over time ${ }^{[2]}$. It frequently leads to acute kidney injury (AKI), which is a life-threatening clinical condition; having high morbidity and prolonged hospitalization of patients and consequent high mortality rate ${ }^{[3]}$.

Renal IRI occurs frequently during the postoperative period of partial nephrectomy, the surgical repair of traumatic kidney lesions, and during renal transplantation. However the reperfusion is more destructive and causes injury to the renal tissues by a number of mechanisms, such as the release of free radicals, oxidative stress, inflammation, glomerular necrosis, leukocyte infiltration, and stimulation of apoptosis ${ }^{[1,4]}$.

Among the variety of mediators that take part in IRI, renin-angiotensin system (RAS) has progressively presumed to have an important role. RAS consists of several peptides that act together in a cascading manner to produce angiotensin II (AT-2) that contributes largely to renal injury. Renin is the enzyme in charge for catalyzing angiotensinogen to angiotensin I, which is then converted by angiotensin converting enzyme (ACE) to active AT-2. Therefore, the effect of RAS can be blocked by renin inhibition ${ }^{[5]}$.

Until recently direct renin inhibition has not been clinically successful; because of the lack of good bio $\neg$ availability or potency. Aliskiren (ALS) is the first oral direct renin inhibitor that has been approved by the US Food and Drug Administration ${ }^{[6]}$. It has been proved to have favorable effects in differ $\frown$ ent renal conditions ${ }^{[7,8,9,10]}$. 
Therefore, this study was planned to explore the effect of direct renin inhibition by aliskiren on renal IRI. This included serum antioxidant superoxide dismutase, kidney function parameters (blood urea nitrogen and serum creatinine), histological and immunohistochemical examination for detecting inflammation and apoptosis. This was followed by morphometric and statistical analysis for the obtained data.

\section{MATERIALS AND METHODS}

\section{Material}

\section{Drugs}

- Aliskiren (ALS): It carries the trade name "Tekturna" (Novartis Pharma Stein AG, Stein, Basle, Switzerland) and was supplied as tablets, each of $150 \mathrm{mg}$, that was dissolved in saline.

- Ketamine: It has the trade name "ketalar" (Pfizer, NJ, USA) and was purchased as $20 \mathrm{~mL}$ vials containing ketamine hydrochloride $10 \mathrm{mg} / \mathrm{mL}$ solution for injection.

- Xylazine: It has trade name "Xyla-Ject" (Adwia Pharmaceuticals, Cairo, Egypt). It was supplied as $50 \mathrm{~mL}$ vials containing xylazine hydrochloride $2 \mathrm{mg} / \mathrm{mL}$ solution for injection.

\section{Animals and experimental design}

Thirty adult male albino rats were included, with average body weight 180-200 grams. Animals were provided with veterinary care by the Animal House of Faculty of Medicine, Cairo University. They were caged in a conventional clean facility at $22-25^{\circ} \mathrm{C}$ and allowed food and water ad libitum. All animal experiments were carried out in strict compliance with the guidelines provided by the Animal Ethics Committee, Faculty of medicine, Cairo University, for the care and use of laboratory animals. The rats were equally divided into 3 groups, 10 rats each.

- Group I (Control group): Rats were subdivided into:

- Subgroup IA: Served as negative control and were sham-operated only.

- Subgroup IB: Sham-operated control rats that were given saline twice orally via gastric tube; 24 hours and 1 hour prior to laparotomy. They were subjected to the same surgical procedure as groups II and III without induction of IRI.

- Group II (IRI group): Rats were subjected to $45 \mathrm{~min}$ of left renal ischemia followed by $24 \mathrm{~h}$ of reperfusion ${ }^{[11]}$.

- Group III (ALS group): Rats were given aliskiren (ALS; $100 \mathrm{mg} / \mathrm{kg}$ ) twice orally via gastric tube; $24 \mathrm{~h}$ and $1 \mathrm{~h}$ prior to induction of ischemia, and then subjected to $45 \mathrm{~min}$ of left renal ischemia followed by 24 hours of reperfusion ${ }^{[5]}$.

\section{Induction of renal IRI model}

Rats were anesthetized with injection of ketamine
$(50 \mathrm{mg} / \mathrm{kg})$ and xylazine hydrochloride $(10 \mathrm{mg} / \mathrm{kg})$ both intraperitoneally. Hair shaving and disinfection of the abdominal wall using povidone iodine was performed, followed by a midline abdominal incision, and then the left renal pedicle was occluded with a non traumatic microvascular clamp for $45 \mathrm{~min}$. The efficiency of occlusion was established by the change in the color of kidney. During this time the rats were kept warm using a thermal pad. After $45 \mathrm{~min}$, the clips were removed to allow blood reperfusion; the kidneys were checked for a change in color within $3 \mathrm{~min}$ to ensure reperfusion, and then the incision was then sutured ${ }^{[4,5,12]}$.

\section{Methods}

\section{Laboratory investigations}

At the end of 24 hours of reperfusion, blood samples were taken from tail vein in heparinized tubes and sent to the Medical Biochemistry Department, Faculty of Medicine, Cairo University, to measure the levels of blood urea nitrogen (BUN), serum creatinine ( $\mathrm{SCr}$ ) and superoxide dismutase enzyme (SOD).

\section{Histological examination}

Rats were sacrificed 24 hours after kidney reperfusion with intraperitoneal injection of $60 \mathrm{mg} / \mathrm{kg}$ pentobarbital sodium $^{[13]}$. Left kidney specimens were fixed in $10 \%$ buffered formalin then embedded in paraffin. Serial sections of 5-7 $\mu \mathrm{m}$ thickness were cut and subjected to:

a. Hematoxylin and eosin stain ${ }^{[14]}$.

b. Periodic acid Schiff reaction (PAS $)^{[14]}$

c. Immunohistochemicalstain ${ }^{[15]}$ forcyclooxygenase-2 (COX-2) antibody, which is a rabbit polyclonal antibody (NeoMarkers, Lab Vision Corporation, CA, USA). COX-2 reaction appears as brown cytoplasmic deposits.

d. Immunohistochemical $\operatorname{stain}^{[15]}$ for caspase-3 antibody, which is a rabbit polyclonal antibody (Thermo Fisher scientific Laboratories, MA, USA). Caspase-3 marker shows brown cytoplasmic and nuclear localization.

\section{Morphometric study}

This was done using "Leica Qwin 500" software image analyzer computer system (Leica image system Ltd; Cambridge, England), and was done using an objective lens of $\mathrm{x} 40$ magnification and were detected in 10 nonoverlapping randomly chosen fields for each section (except the size of Malpighian renal corpuscles). The following parameters were measured:

a. Size of Malpighian renal corpuscles was detected in 30 randomly chosen corpuscles per section

b. Optical density of PAS +ve reaction

c. The area percent of COX-2 immunoexpression

d. The area percent of caspase-3 immunoexpression 


\section{Statistical Analysis}

It was done for the laboratory and morphometric results. Data were statistically analyzed using statistical package SPSS version 16 (SPSS Inc., Chicago, USA). Comparisons between groups were done using ANOVA (analysis of variance) followed by post hoc test for multiple comparisons between each 2 groups. Data were expressed as mean and standard deviation (SD) for the quantitative variable. Results were considered significant when $p<0.05^{[16]}$.

\section{RESULTS}

\section{Mortality}

Two animals from group II (IRI group) and one animal from group III (ALS group) died during the 24 hours of reperfusion, and they were excluded from the study.

\section{Laboratory investigations results}

Laboratory investigation results are illustrated in (Table 1)

\section{Histological Results}

\section{Hematoxylin and Eosin-stained sections}

Sections from both control subgroups (IA and IB) showed similar picture with no differences. The renal cortex presented normal histological architecture; the Malpighian renal corpuscle (MRC) appeared formed of tuft of glomerular capillaries surrounded by Bowman's space that was lined by simple squamous epithelium. The proximal convoluted tubules (PCT) were lined with cuboidal cells with rounded basal nuclei and and apical clear brush borders, so having narrow lumina. The distal convoluted tubules (DCT) were lined with cubical cells with rounded central nuclei and nonclear brush border, thus having wider lumina (Figures 1 and 2).

Renal cortical sections from group II (IRI group) revealed some enlarged MRC with large segmented glomeruli, while other MRC appeared small with small or even atrophic glomeruli leaving a wide Bowman's space. The renal interstitium showed focal areas of inflammatory cells infiltration and congested blood vessels (Figure 3). The PCT were seen with almost lost brush border. Many of the tubular lining cells show vacuolated cytoplasm and some cells were completely detached and presented small pyknotic nuclei and minimal cytoplasm. Other cells showed disintegrated very faint nuclei. Cell ghosts were also detected. Some renal tubules displayed desquamated epithelium lining and casts within their lumina in the form of sloughed cytoplasmic fragments or cellular debris. The basement membranes of both the glomeruli and renal tubules appear interrupted at some areas (Figure 4).
Sections from group III (ALS group) showed apparently normal MRC containing normal glomeruli that were surrounded with Bowman's space. Most PCT preserved their brush borders but few tubular cells appeared with small darkly stained shrunken nuclei. Few renal tubules showed sloughed cytoplasmic fragments or cellular debris within their lumens (Figures 5 and 6).

\section{PAS stained sections}

Examined renal cortex form group I (control group) exhibited a strong PAS-positive reaction in the apical brush borders of the cells lining the PCT, in addition to the basement membranes of the MRC, the glomeruli and the renal tubules (Figure 7). Sections from group II (IRI group) displayed weak interrupted PAS staining of the apical brush borders of some PCT, while others showed complete loss of their brush borders. Also, PAS-positive casts were seen inside the tubular lumina. In addition a weak PAS-positive reaction was detected in the basement membranes of the MRC, the glomeruli and the renal tubules (Figure 8). Whereas examined sections from group III (ALS group) showed a strong PAS-positive reaction in the apical brush borders of the cells lining the PCT, in addition to the capsular, glomerular and tubular basement membranes (Figure 9).

\section{Immunohistochemical results}

\section{COX-2 immunostained sections}

The examined renal cortex from the control (group I) showed scarce brown COX-2 immunoreaction, which appeared in the cytoplasm of the cells of macula densa. But there was negative immunoreaction in PCT, DCT and glomeruli (Figure 10). As for group II (IRI group), marked brown cytoplasmic COX-2 immunoreactivity in the cells of macula densa and DCT were evident. Cells of the PCT and glomeruli showed moderate immunoreaction (Figure 11). Group III (ALS group) revealed mild COX-2 immunoreactivity in few cells of macula densa and DCT. However cells of the PCT and glomeruli exhibited almost negative immunoreaction (Figure 12).

\section{Caspase-3 immunostained sections}

Renal cortical sections from Group I (control group) presented negative caspase-3 immunoreactivity in the PCT, DCT and the glomeruli (Figure 13). Sections from group II (IRI group) showed widespread caspase-3 immunoreaction in the cytoplasm and nuclei of the cells of PCT, DCT and glomeruli (Figure 14). Regarding group III (ALS group); there was mild caspase- 3 immunoreactivity in cells of the PCT, DCT and the glomeruli (Figure 15).

\section{Morphometric results}

Morphometric results are illustrated in (Table 2 and Histograms 1,2,3). 


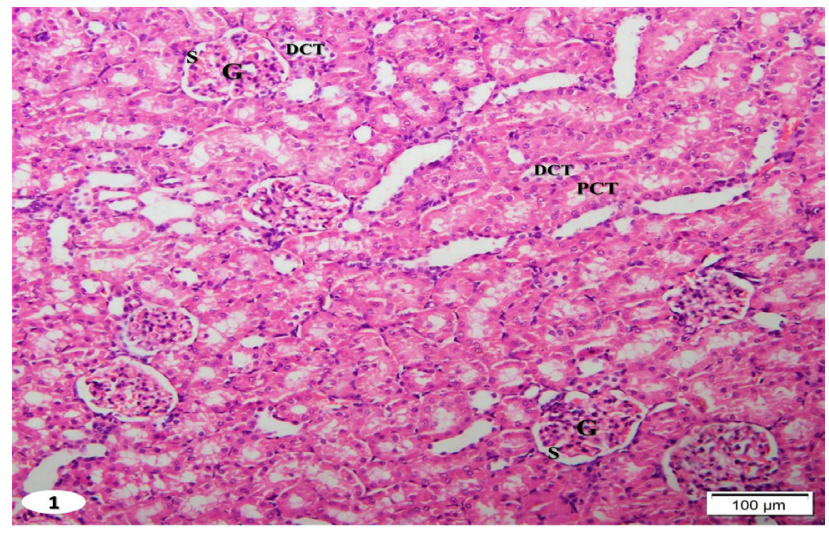

Fig. 1: Photomicrograph of a section in the renal cortex of a rat from Group I (control group) displaying Malpighian renal corpuscles containing glomeruli $(\mathrm{G})$ and surrounded with Bowman's space (S). Proximal convoluted tubules (PCT) appear with narrow lumina and apical clear brush borders. Distal convoluted tubules (DCT) appear with wider lumina and nonclear brush border. (HandE X100)

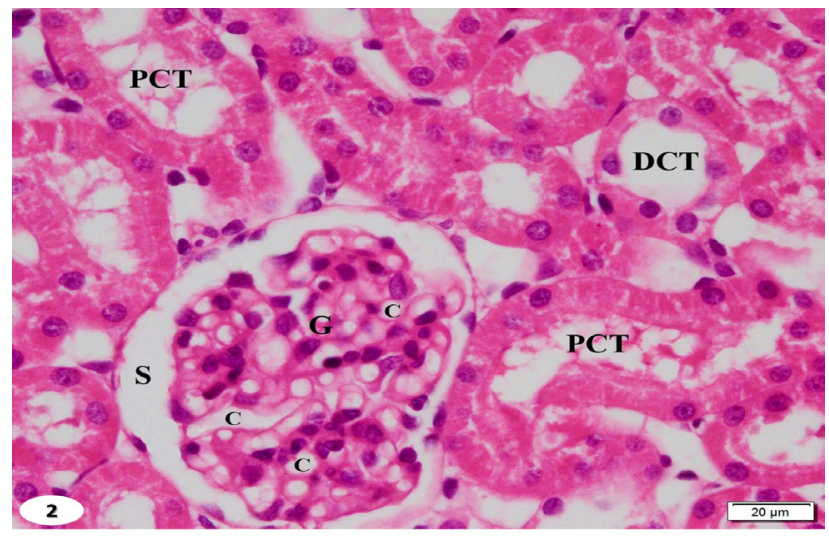

Fig. 2: Photomicrograph of a section in the renal cortex of a rat from Group (control group). It shows Malpighian renal corpuscle containing glomerulus (G) with many capillaries (C) and surrounded with Bowman's space (S) which is clear of any cell debris. The parietal layer of Bowman's capsule is lined by flat squamous cells resting on a basement membrane. Proximal convoluted tubules (PCT) appear with rounded basal vesicular nuclei and apical clear brush borders. Distal convoluted tubule (DCT) appears with central rounded nuclei and nonclear brush border. (HandE X400)

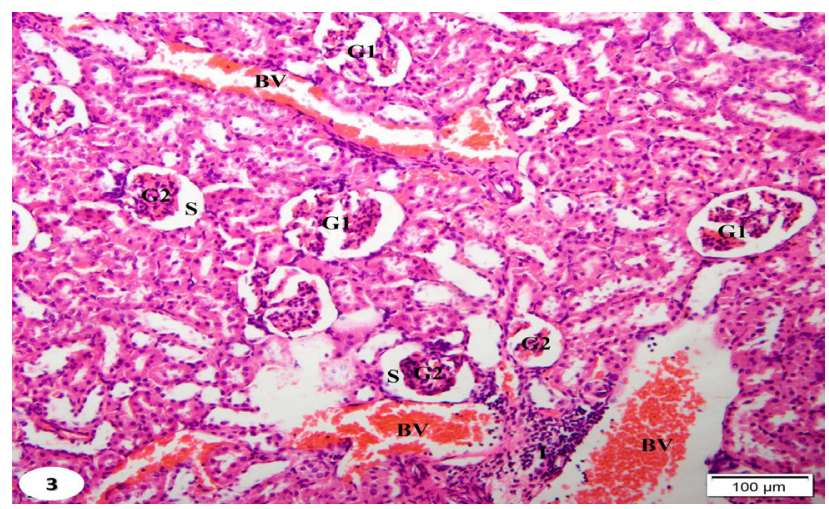

Fig. 3: Photomicrograph of a section in the renal cortex of a rat from Group II (IRI group) reveals enlarged renal corpuscles with large segmented glomeruli (G1) while others appear small with small glomeruli or even atrophic (G2), leaving a wide Bowman's space (S). The renal interstitium showed focal areas of infiltration with inflammatory cells (I) and congestion of blood vessels (BV). (HandE X100)

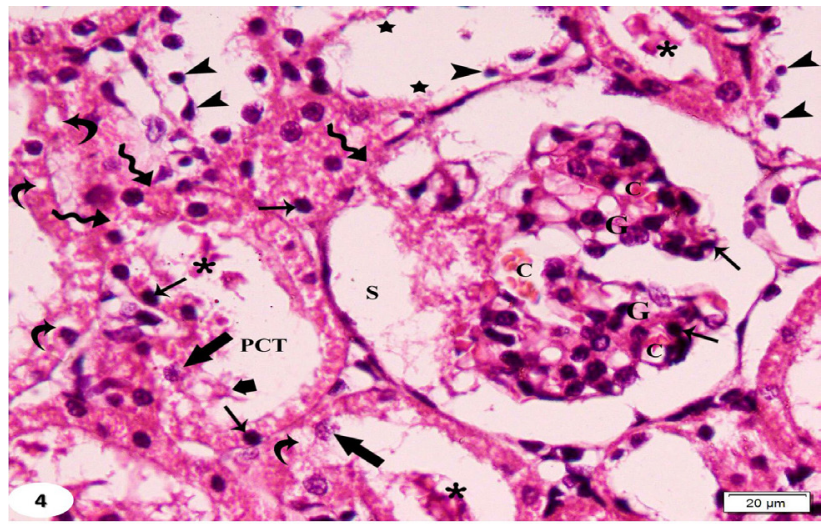

Fig. 4: Photomicrograph of a section in the renal cortex of a rat from Group II. It displays segmented glomerulus $(\mathrm{G})$ with dilated congested capillaries (C) and dilated Bowman's space (S) filled with cell debris. Many tubular and glomerular cells have small darkly stained nuclei (thin arrows). Proximal tubule is seen with almost lost brush border (PCT). Many tubular lining cells show vacuolated cytoplasm (curved arrows). Some tubular cells are detached with small dark nuclei and minimal cytoplasm (arrowheads) while others have disintegrated nuclei (thick arrows). Cell ghost is also detected (short arrow). Some renal tubules show desquamated epithelial lining (stars) and casts (sloughed cytoplasmic fragments/ cellular debris) within their lumina (asterisk). The glomerular and tubular basement membranes appear interrupted (wavy arrows). (HandE X400)

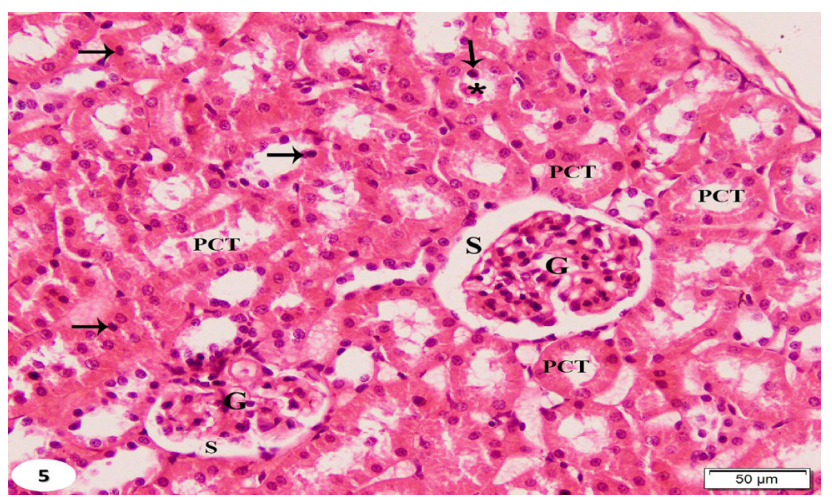

Fig. 5: Photomicrograph of a section in the renal cortex of a rat from Group III (ALS group) showing apparently normal Malpighian renal corpuscle containing apparently normal glomerulus $(\mathrm{G})$ and Bowman's space (S). Most proximal convoluted tubules (PCT) have regained their brush borders. Some tubular cells still have small darkly stained shrunken nuclei (arrows). A cast is seen within the tubular lumen (asterisk). (HandE X200)

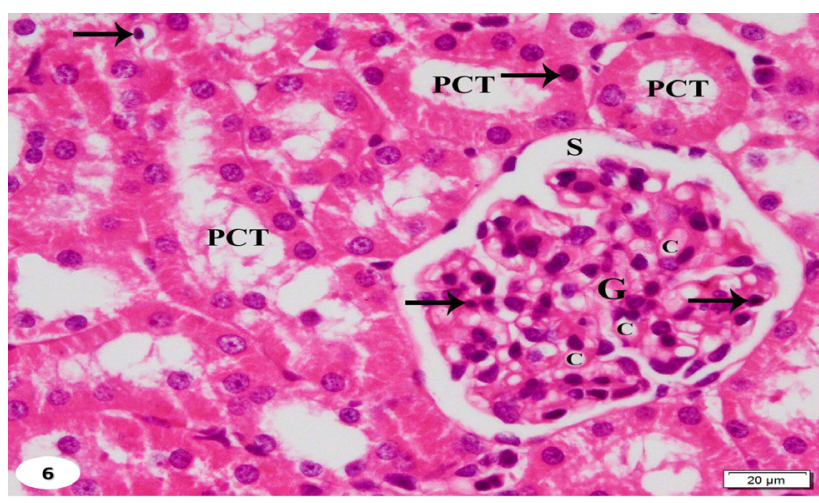

Fig. 6: Photomicrograph of a section in the renal cortex of a rat from Group III with apparently normal Malpighian renal corpuscle containing glomerulus (G) with many capillaries (C) and surrounded by Bowman's space (S). Most proximal convoluted tubules (PCT) preserve their brush borders. Few tubular and glomerular cells still have small darkly stained shrunken nuclei (arrows). (HandE X400) 


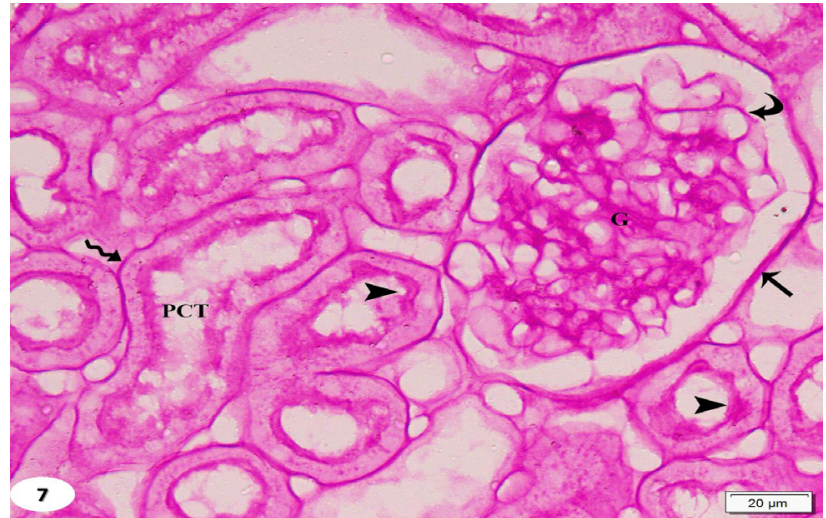

Fig. 7: Photomicrograph of a section in the renal cortex from a control rat showing a strong PAS-positive reaction in the apical brush borders of cells lining PCTs (arrowheads), in addition to the capsular basement membrane (arrow), tubular basement membrane (wavy arrow) and glomerular basement membrane (curved arrow). (PAS X400)

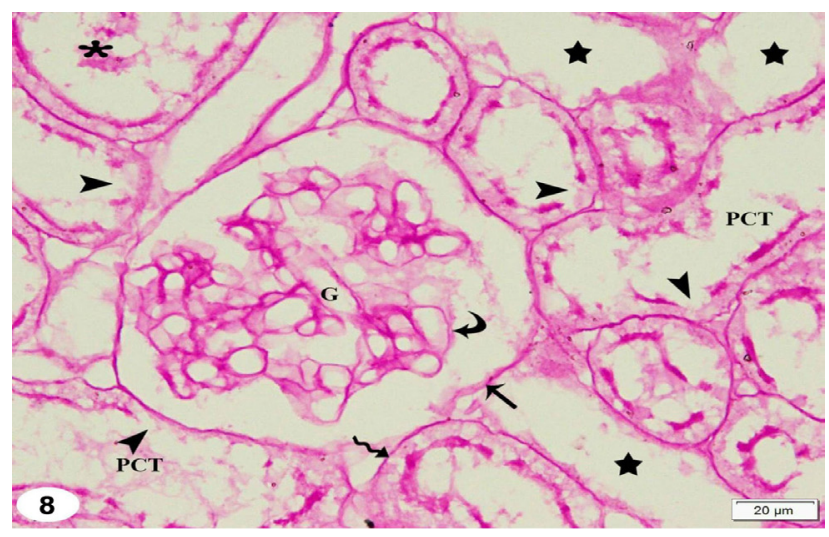

Fig. 8: Photomicrograph of a section in the renal cortex of a rat from Group II (IRI group) revealing weak PAS-positive reaction in the capsular basement membrane (arrow), tubular basement membrane (wavy arrow) and the glomerular basement membrane (curved arrow). Some tubules show weak interrupted staining of the apical brush borders (arrowheads), while others show complete loss of the brush borders (stars). A PASpositive cast (asterisk) is also seen inside the tubular lumen. (PAS X400)

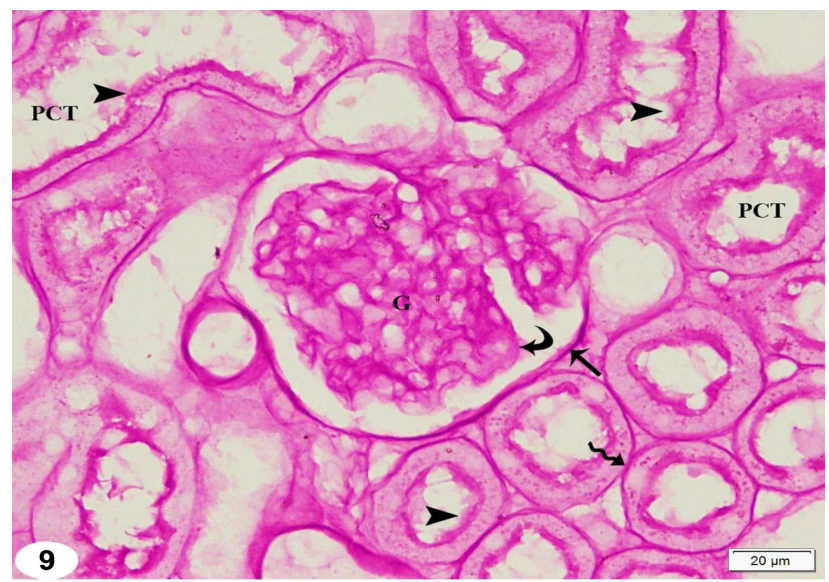

Fig. 9: Photomicrograph of a section in the renal cortex of a rat from Group III (ALS group) displays a strong PAS-positive reaction in the apical brush borders of the cells lining PCTs (arrowheads), in addition to the capsular basement membrane (arrow), tubular basement membrane (wavy arrow) and the glomerular basement membrane (curved arrow). (PAS X400)

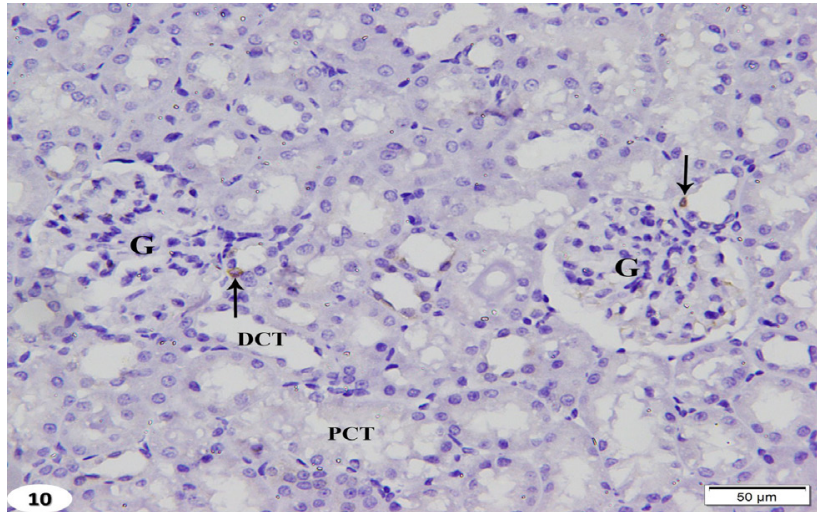

Fig. 10: Photomicrograph of a section in the renal cortex from a control rat presenting scarce brown cytoplasmic immunoreactivity to COX-2 in the cells of macula densa (arrows) and negative immunoreaction in PCT, DCT and glomerulus (G). (COX-2 X200)

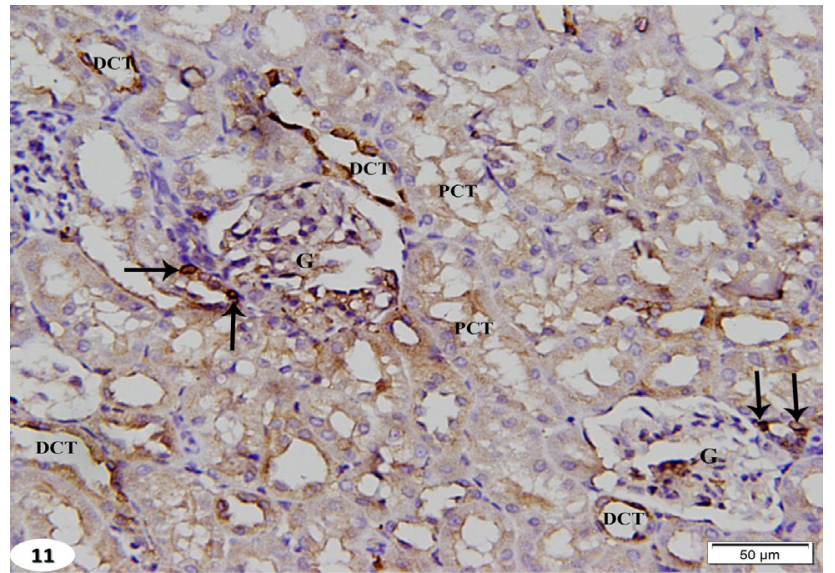

Fig. 11: Photomicrograph of a section in the renal cortex of a rat from Group II shows marked brown cytoplasmic COX-2 immunoreactivity in the cells of macula densa (arrows) and distal convoluted tubules (DCT). Cells of the proximal convoluted tubules (PCT) and glomerulus $(\mathrm{G})$ reveal moderate immunoreaction. (COX-2 X200)

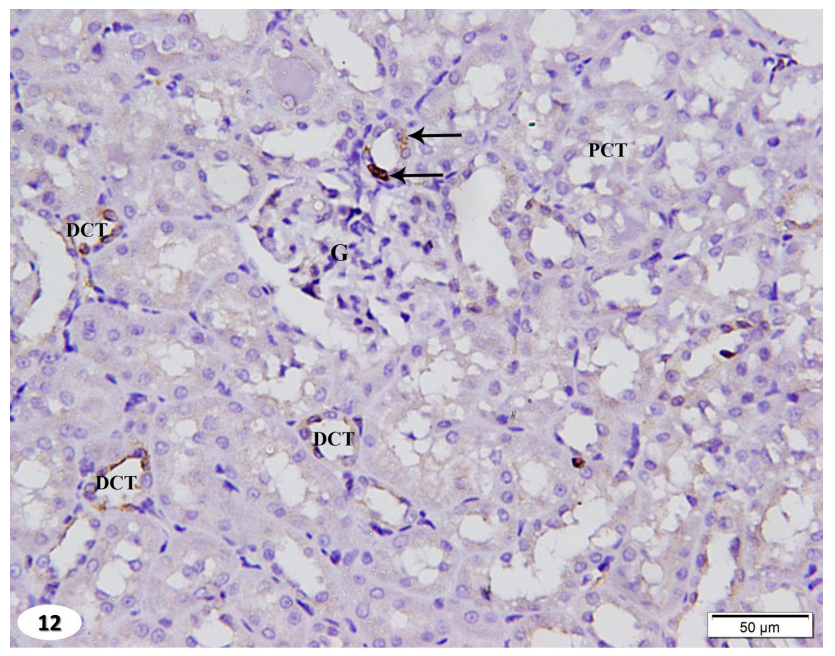

Fig. 12: Photomicrograph of a section in the renal cortex of a rat from Group III shows mild COX-2 immunoreactivity in few cells of macula densa (arrows) and distal convoluted tubules (DCT). Cells of proximal convoluted tubules (PCT) and glomerulus (G) show almost negative immunoreaction. (COX-2 X200) 


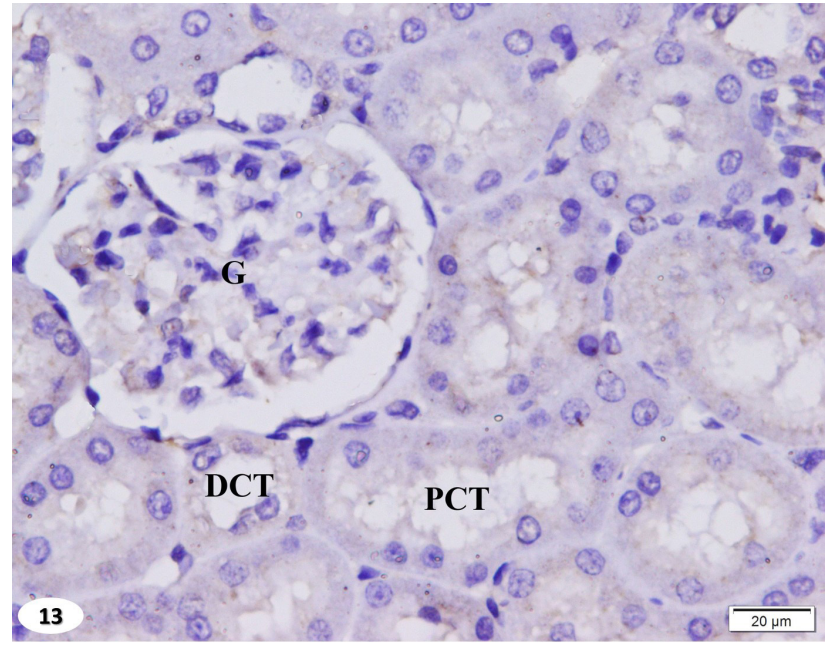

Fig. 13: Photomicrograph of a section in the renal cortex of a rat from Group I (control) displaying negative caspase-3 immunoreactivity in the PCT, DCT and the glomerulus (G). (Caspase-3 X400)

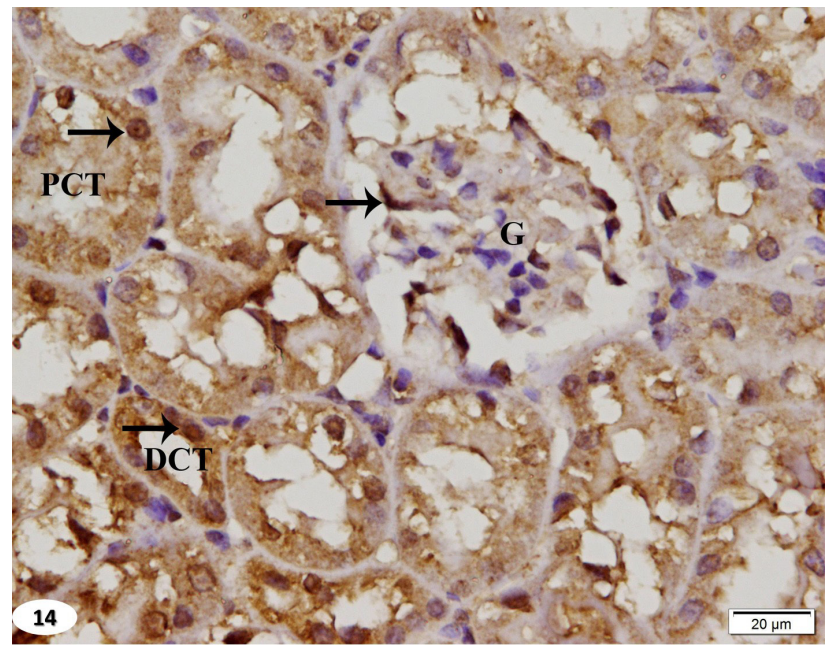

Fig. 14: Photomicrograph of a section in the renal cortex of a rat from Group II shows widespread caspase-3 immunoreaction in the cytoplasm and nuclei of the cells of PCT, DCT and glomerulus (G) (arrows). (Caspase-3 X400)

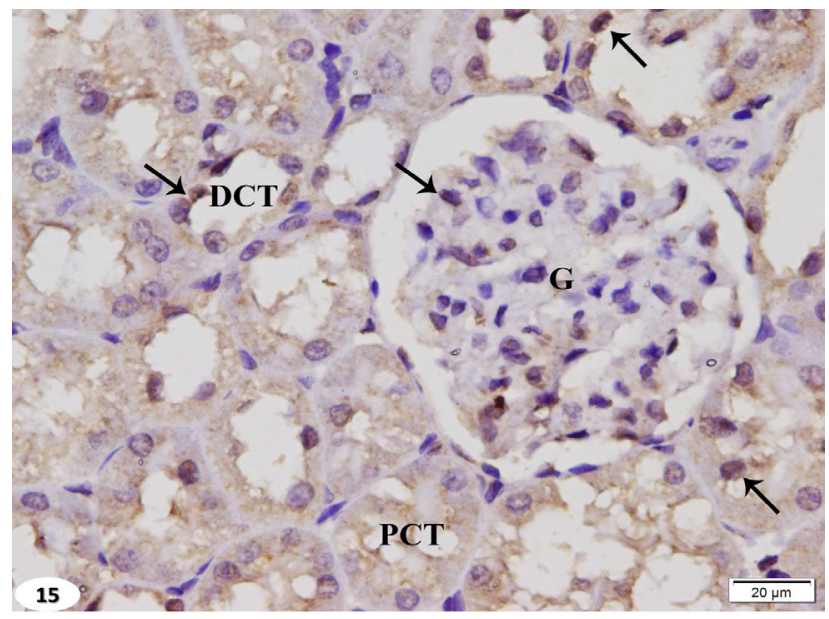

Fig. 15: Photomicrograph of a section in the renal cortex of a rat from Group III revealing mild caspase-3 immunoreactivity in cells of the PCT, DCT and the glomerulus $(\mathrm{G})$ (arrows). (Caspase-3 X400)
Table 1: Mean values $( \pm \mathrm{SD})$ of chemical parameters in the studied groups.

\begin{tabular}{lccc}
\hline Parameters & $\begin{array}{c}\text { Group I } \\
\text { (Control) }\end{array}$ & $\begin{array}{c}\text { Group II } \\
\text { (IRI group) }\end{array}$ & $\begin{array}{c}\text { Group III } \\
\text { (ALS group) }\end{array}$ \\
\hline BUN (mg/dl) & $35.8 \pm 1.5$ & $85.3 \pm 3.3^{*}$ & $51.23 \pm 2.4^{*}$ \\
$\mathrm{SCr}(\mathrm{mg} / \mathrm{dl})$ & $0.35 \pm 0.02$ & $1.92 \pm 0.15^{*}$ & $1.3 \pm 0.05^{*}$ \\
$\mathrm{SOD}(\mathrm{U} / \mathrm{L})$ & $86.0 \pm 6.2$ & $67.7 \pm 4.1^{\circ}$ & $81.0 \pm 7.1^{\#}$ \\
\hline
\end{tabular}

* Increased significantly versus group I.

$\square$ Decreased significantly versus groups II.

- Decreased significantly versus groups I

\# Increased significantly versus group II with no significant difference versus group I.

Table 2: Mean values $( \pm \mathrm{SD})$ of morphometric parameters in the studied groups

\begin{tabular}{cccc}
\hline Parameters & $\begin{array}{c}\text { Group I } \\
\text { (Control) }\end{array}$ & $\begin{array}{c}\text { Group II } \\
\text { (IRI group) }\end{array}$ & $\begin{array}{c}\text { Group III } \\
\text { (ALS group) }\end{array}$ \\
\hline $\begin{array}{c}\text { Mean area of } \\
\text { renal corpuscles } \\
\left(\mu \mathrm{m}^{2}\right)\end{array}$ & $4341.06 \pm 1235.2$ & $9259.38 \pm 2115.3^{*}$ & $4567.65 \pm 1315.7^{\#}$ \\
$\begin{array}{c}\text { Optical density } \\
\text { of PAS }\end{array}$ & $1.98 \pm 0.21$ & $0.67 \pm 0.13^{\circ}$ & $1.84 \pm 0.17^{\#}$ \\
$\begin{array}{c}\text { Mean area \% } \\
\text { of COX-2 }\end{array}$ & $1.02 \pm 0.2$ & $19.36 \pm 4.3^{*}$ & $7.68 \pm 1.71^{*} \square$ \\
$\begin{array}{c}\text { Mean area \% } \\
\text { Caspase-3 }\end{array}$ & $1.66 \pm 0.05$ & $20.34 \pm 3.05^{*}$ & $9.13 \pm 2.11^{*}$ म \\
\hline
\end{tabular}

* Increased significantly versus group I.

\# Decreased significantly versus group II with no significant difference versus group I.

$\circ$ Decreased significantly versus groups I

$\square$ Decreased significantly versus groups II.

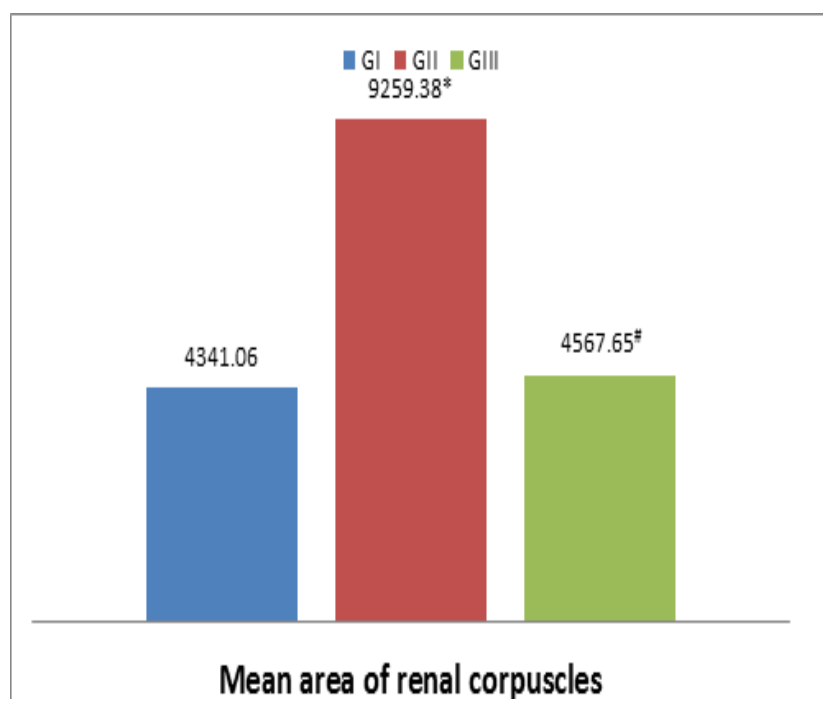

Histogram 1: Mean values $( \pm \mathrm{SD})$ of renal corpuscles' area $(\mu \mathrm{m} 2)$ in the studied groups. 


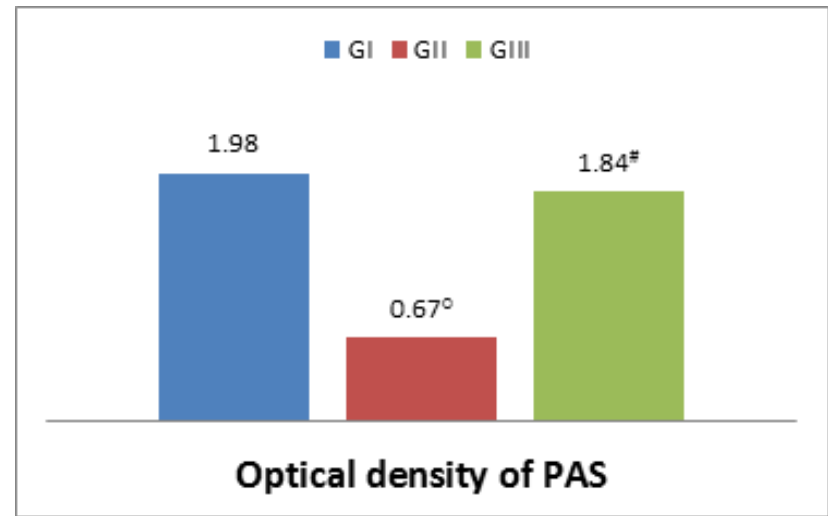

Histogram 2: Mean values ( \pm SD) of optical density of PAS in the studied groups.

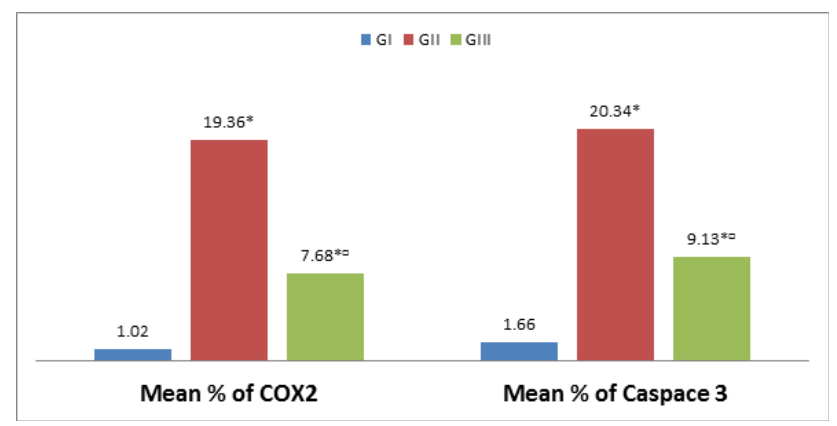

Histogram 3: Mean values $( \pm \mathrm{SD})$ of area $\%$ of COX2 and Caspase 3 immunoreactivity in the studied groups.

\section{DISCUSSION}

Renal Ischemia/reperfusion injury (IRI) can be induced in experimental animals via two different methods, either unilateral renal pedicle or renal artery clamping or bilateral renal pedicle or renal artery clamping. Additionally, the duration of renal ischemia is imperative and generally it is limited to 30-60 minutes, because this ischemia time allows for intermediate survival. If it is more than 60 minutes, it will lead to acute tubular necrosis and renal failure. Renal ischemia of less than 30 minutes results in rapid proliferation of tubular epithelial cells and repair of the damaged renal tubules, which is accompanied by improved renal functions. Accordingly, 45 minutes of renal ischemia is found to cause findings of IRI regarding tubular epithelial cell injury and irreversible acute tubular necrosis with a known survival rate of $100 \%$ at 7 days and $85 \%$ at 30 days in rats. This may be followed by reperfusion for $4,6,12$, or $24 \mathrm{~h}^{[4,12,17]}$. In view of that, the rat model of renal IRI in this work was established by left renal pedicle occlusion for 45 minutes followed by reperfusion for $24 \mathrm{~h}$.

In the present study, the influence on renal functions after IRI (group II) was established based on the significant increase in BUN and SCr levels. This is in agreement with previous studies carried on renal IRI models ${ }^{[5,18,19,20,21]}$. Renal ischemia results in functional impairment through a combination of events; renal vasoconstriction, tubular obstruction, reduced glomerular permeability and tubular back-leakage of glomerular filtrate ${ }^{[22]}$. Several mechanisms were found to exacerbate the cellular injury resulting from reperfusion of ischemic tissues as oxygen free radicals that account for increasing oxidative stress and the expression of pro-apoptotic mediators and inflammatory cytokines ${ }^{[19,21]}$.

Furthermore, there was a significant decrease in the serum level of SOD following IRI and this is in harmony with other researches ${ }^{[5,19,20]}$. SOD is an important endogenous antioxidant enzyme that plays a fundamental and crucial role in the antioxidant protective capability of biological systems against reactive oxygen species (ROS). It is the first detoxification enzyme that catalyzes the dismutation of two molecules of superoxide anion, which plays a primary role in oxidative stress and damage, to hydrogen peroxide and molecular oxygen, consequently rendering it less hazardous ${ }^{[23]}$.

During IRI, the injured tissue produce excessive amount of ROS that changes mitochon $\neg$ drial oxidative phosphorylation, causing ATP depletion, increase in intracellular calcium and thus activation of membrane phos $\neg$ pholipids proteases ${ }^{[24]}$. In addition, among the oxide radicals present, there are superoxide and hydroxyl nitric oxide, leading to formation of peroxynitrite and nitric oxide, which add up to the cellular damage ${ }^{[5]}$. Simultaneously, the blood flow during re-perfusion can produce oxygen free radicals that cause renal tissue injury via membrane lipids peroxidation and oxidative damage of DNA and proteins contrib $\neg$ uting to apoptosis and cell death. Besides, down regu-lation of the antioxidant enzymes such as SOD is to be blamed for the pathophysiology of IRI ${ }^{[24]}$.

The histological findings regarding the IRI group (group II) was in line with the laboratory results, where renal IRI exerted notable injurious effect on the cortex. The renal cortex has the highest level of oxygenation followed by the outer medulla, and the lowest levels in the inner medulla and papillae. Consequently, the cortical cells are the most susceptible to ischemia, while cells in the outer medulla can alter to metabolism independent on oxygen, and the inner medullary and papillae cells depend mainly on anaerobic glycolysis ${ }^{[25]}$.

Examined HandE and PAS-stained sections from IRI group revealed marked glomerular and tubular alterations. Some glomeruli appeared enlarged, while others were atrophic leaving a wide Bowman's space with interrupted or thin basement membranes at some areas; this could be attributed to the acute and severe renal injury. Previous electron microscopic studies on renal IRI confirmed the degeneration of glomeruli, disappearance of capillaries' basement membranes, together with necrosis of mesangial and podocytic cells ${ }^{[5]}$. Moreover renal IRI is accompanied by changes in the glomerular filtration capability because of the vasoconstriction of pre-arteriolar capillaries due in part to endothelial injury together with vasoactive cytokines produced from leucocytes; all these reduce the glomerular forces for filtration and create a state of overwork in the glomeruli ${ }^{[26,27]}$. 
Regarding the tubular changes, these were obvious in the PCT; some lining cells had vacuolated cytoplasm, others were completely detached and showed minimal cytoplasm and small pyknotic nuclei or disintegrated very faint nuclei. The brush border was lost and desquamated epithelial cells with intraluminal casts could be seen. Also, the tubular basement membranes appeared interrupted at some areas. These findings are consistent with previous studies $^{[2,3,5,18,19,28]}$. Previous electron microscopic studies found that PCT lost their apical microvilli with the presence of cytoplasmic vacuolation and distortion of basal membrane infoldings ${ }^{[26]}$.

It is worth to mention that during ischemia, all the nephron segments can be affected, but the PCT cells are usually the most injured; because they have a high metabolic rate plus a limited capacity to carry out anaerobic glycolysis ${ }^{[25]}$. On the contrary, DCT have a greater capacity to change to glycolytic metabolism, hence adapt better to ischemia. In addition, they have higher capacity to produce the anti-apoptotic protein Bcl-2 than PCT, which makes them more resistance to ischemic injury[29].

Moreover, the renal interstitium showed inflammatory cells infiltration with congested blood vessels. This was encountered by other researchers too ${ }^{[18,20,28]}$. It was proved that inflammation is a major contributor to the pathogenesis of IRI. Following ischemia, the injured PCT cells generate a number of potent mediators including pro-inflammatory cytokines as tumor necrosis factor (TNF), and interleukins (IL) $-6,-1 \beta$ and -8 . Also, the extravasated leucocytes release toxic ROS, elastases and proteases, leading to increased microvascular permeability, thrombosis and parenchymal cell death ${ }^{[18,25]}$.

In the present study, the inflammation and apoptosis found in the IRI sections were further confirmed by the immunohistochemical stains for both cyclooxygenase-2 (COX-2) and caspase- 3 enzymes respectively, where there was a significant increase in their mean area percent as compared to the control, and this is in accordance with other studies ${ }^{[3,20,21]}$.

Arachidonic acid metabolites have vital role in mediating inflammation and inflammatory cytokine production. This acid is released from the plasma membrane and then metabolized by COX-1 and COX2 into prostaglandins, prostacyclins and thromboxanes. COX-1 is expressed constitutively, but COX-2 expression is induced by inflammatory stimuli or mediators. Both prostaglandins and thromboxanes induce the production of cytokines and chemokines, which mediate the activation of neutrophils and monocytes with subsequent release of inflammatory mediators that cause renal IRI ${ }^{[30]}$. Studies have found that normally COX-2 expression in renal cortex is localized to the macula densa ${ }^{[31]}$. This is explained by the fact that COX-2 is the source of macula densa-derived prostaglandins that mediate the expression and release of renin by juxtaglomerular cells, that is why it is present at little but detectable levels in the macula densa under normal conditions, and induction of a high-renin state significantly increases COX-2 expression by the macula densa ${ }^{[32]}$. During $\mathrm{AKI}$, in addition to macula densa, it is also expressed in the medullary interstitial cells, the endothelium of arteries and veins and glomerular podocytes ${ }^{[31]}$. Plus, it has been proved to have an important role during IRI; as its expression is up-regulated because of the pro-inflammatory cytokines such as ILs and TNF. In addition, its induction involves ROS generation and prostanoids synthesis which are potent inflammatory mediators that exacerbate the inflammatory process $^{[33]}$.

During hypoxia, there is accumulation of intracellular calcium that results in caspase activation in ischemic tissues and is an indicator of cell death ${ }^{[12]}$. Besides, following the decrease in effective kidney perfusion, epithelial cells cannot preserve sufficient intracellular ATP for essential processes, so cell death by necrosis or apoptosis occurs ${ }^{[25]}$. Adding up, oxidative stress leads to activation of the proapoptotic Bax protein, which is mainly localized in renal tubular cells, and it plays an important role in the apoptotic cascade, where it promotes caspase- 3 activation ${ }^{[21]}$.

Renin-angiotensin system (RAS) activation and elevation of angioten $\neg \sin$ II (AT-2) level are the essential risk factors in IRI. AT-2 results in renal injury via constriction of renal vessels, enhancement of vascular sensitivity to sympathetic nerve stimulation, oxidative stress and induction of apoptosis. That is why RAS inhibition has a protective effect against renal IRI ${ }^{[24]}$. RAS can be blocked at different levels by agents such as renin inhibitors, angiotensin converting enzyme (ACE) inhibitors, and angiotensin receptor blockers (ARB). Renin inhibition is more effective than the ACE inhibitors or the ARBs that have shown to cause a compensatory increase in the renin level thus decrease their potential effects ${ }^{[9]}$. Aliskiren (ALS) is a direct renin inhibitor that proved to have an anti-proteinuric effect in patients with diabetes and also exerts anti-atherosclerotic, cardioprotective, renoprotective, antioxidant, anti-inflammatory and antiapoptotic effects independent of its lowering effect on blood pressure ${ }^{[9,10]}$. Also it has been established to have beneficial effects in different renal conditions ${ }^{[6,8,9,10]}$.

In the present study, pretreatment with ALS in group III resulted in significant decrease in the levels of BUN and $\mathrm{SCr}$, which might indicate its protective effect against IRI induced impairment of renal function. In addition, its antioxidant action was proved as it significantly increased SOD level as compared to IRI group, and this was demonstrated by other researchers ${ }^{[5,10,11,20]}$. Since RAS activation aggravates the oxidative stress which further enhances AT-2 activity ${ }^{[22]}$. Hence, blockade of RAS by ALS could lessen the oxidative stress induced damage ${ }^{[5,9,11]}$.

Regarding the histological findings of HandE and PAS-stained sections from ALS group (group III), MRC appeared almost normal with normal glomeruli surrounded with Bowman's space. Most PCT preserved their normal histological architecture and brush borders. This was 
accompanied by significant reduction in the mean area percent of COX-2 and caspase- 3 immunoexpression. The observed anti-inflammatory and anti-apoptotic effects shown in this work is in agreement with that obtained before $^{[10,34,35]}$.

The anti-inflammatory effect of ALS might be due to inhibition of AT-2 that regulates the expression of inflammatory markers as cytokines, chemokines and adhesion molecules ${ }^{[36]}$. Furthermore, ALS inhibits the binding of renin and prorenin to the prorenin receptor, which stimulates inflammatory mediators, as transforming growth factor and fibronectin, via the extracellular signal regulated kinase 1 and 2 pathways independent of angiotensin ${ }^{[37]}$. Whereas the anti-apoptotic effect of ALS might be attributed to its antioxidant capability. This could be explained by the fact that oxidative stress disturbs the pro-apoptotic/anti-apoptotic equilibrium and thus activates the mitochondrial dependent apoptosis via caspase-3 pathway ${ }^{[10,38]}$. It is known that intrinsic apoptosis is due to the release of mitochondrial proteins into the cytosol, leading to consequent caspase activation. Mitochondrial integrity is vastly controlled, mainly via interactions between proapoptotic (Bax) and anti-apoptotic (Bcl-2) proteins, which incorporate different death and survival signals to decide the cells fate. Evidence verified that ALS adjusted the balance of apoptosis-regulating proteins by decreasing the Bax to Bcl-2 ratio thus inhibiting apoptosis ${ }^{[39]}$.

\section{CONCLUSION}

The results of the present study demonstrated that ALS could protect against renal cortical IRI in albino rat model; possibly via inhibition of oxidative stress, inflamma $\neg$ tion and subsequent apoptosis. Still, further studies are required to explore the exact mechanisms underlying the effects of ALS before its application as a therapy in case where renal IRI could be encountered.

\section{CONFLICT OF INTEREST}

There are no conflicts of interest.

\section{REFERENCES}

1. Salvadori M, Rosso G, Bertoni E. Update on ischemia-reperfusion injury in kidney transplantation: Pathogenesis and treatment. World J Transplant. 2015; 5(2):52-67.

2. Gao D, Jing S, Zhang Q, Wu G. Pterostilbene protects against acute renal ischemia reperfusion injury and inhibits oxidative stress, inducible nitric oxide synthase expression and inflammation in rats via the Toll-like receptor 4/nuclear factor- $\mathrm{\kappa B}$ signaling pathway. Exp Ther Med. 2018; 15(1):1029-1035.

3. Zhang YL, Zhang J, Cui LY, Yang S. Autophagy activation attenuates renal ischemia-reperfusion injury in rats. Exp Biol Med (Maywood). 2015; 240(12):1590-1598.
4. Medeiros VF, Azevedo ÍM, Carvalho MD, Oliveira CN, Egito ES, Medeiros AC. The renoprotective effect of oral Tadalafil pretreatment on ischemia/reperfusion injury in rats. Acta Cir Bras. 2017 Feb; 32(2): 90-97.

5. Ziypak T, Halici Z, Alkan E, Akpinar E, Polat B, Adanur S, Cadirci E, Ferah I, Bayir Y, Karakus E, Mercantepe T. Renoprotective effect of aliskiren on renal ischemia/reperfusion injury in rats: electron microscopy and molecular study. Ren Fail. 2015; 37(2):343-354.

6. Hammad FT, Lubbad L. The effect of aliskiren on the renal dysfunction following unilateral ureteral obstruction in the rat. Int J Physiol Pathophysiol Pharmacol. 2016; 8(2):70-77.

7. Whaley-Connell A, Nistala R, Habibi J, Hayden MR, Schneider RI, Johnson MS, Tilmon R, Rehmer N, Ferrario CM, Sowers JR. Comparative effect of direct renin inhibition and AT1R blockade on glomerular filtration barrier injury in the transgenic Ren2 rat. Am J Physiol Renal Physiol. 2010; 298:F655-661.

8. Zhou G, Liu X, Cheung AK, Huang Y. Efficacy of aliskiren, compared with angiotensin II block $\neg$ ade, in slowing the progression of diabetic ne $\neg$ phropathy in $\mathrm{db} / \mathrm{db}$ mice: should the combina $\neg$ tion therapy be a focus? Am J Transl Res 2015; 7: 825-840.

9. Hussein AM, Malek HA, Saad MA. Renoprotective effects of aliskiren on adenine-induced tubulointerstitial nephropathy: possible underlying mechanisms. Can J Physiol Pharmacol. 2016; 94(8):829-837.

10. Mahfoz AM, El-Latif HA, Ahmed LA, Hassanein NM, Shoka AA. Anti-diabetic and renoprotective effects of aliskiren in streptozotocin-induced diabetic nephropathy in female rats. Naunyn Schmiedebergs Arch Pharmacol. 2016; 389(12):1315-1324

11. Wang Z, Liu Y, Han Y, Guan W, Kou X, Fu J, Yang D, Ren H, He D, Zhou L, Zeng C. Protective effects of aliskiren on ischemia-reperfusion-induced renal injury in rats. Eur J Pharmacol. 2013; 718(1-3): 160-166

12. Ozbilgin S, Ozkardesler S, Akan M, Boztas N, Ozbilgin M, Ergur BU, Derici S, Guneli ME, Meseri R. Renal Ischemia/Reperfusion Injury in Diabetic Rats: The Role of Local Ischemic Preconditioning. Biomed Res Int. 2016; 2016: 8580475.

13. Pourghasem M, Nasiri E, Shafi H. Early renal histological changes in alloxan-induced diabetic rats. Int J Mol Cell Med .2014; 3: 11-15.

14. Kiernan JA. Histological and Histochemical Methods. Theory and Practice, $5^{\text {th }}$ edition. Scion Publishing Ltd, Banbury, UK. 2015; pp: 1-137.

15. Suvarna SK, Layton C, Bancroft JD: Bancroft's theory and practice of histological techniques, $7^{\text {th }}$ edition. Elsevier Health sciences, Churchill Livingstone. 2013; pp: 492- 538. 
16. Emsley R, Dunn G, White IR. Mediation and moderation of treatment effects in randomised controlled trials of complex interventions. Stat. Methods Med. Res. 2010; 19: 237-270.

17. Fouad AA, Al-Mulhim AS, Jresat I, Morsy MA. Protective effects of captopril in diabetic rats exposed to ischemia/reperfusion renal injury. Journal of Pharmacy and Pharmacology. 2013; 65(2):243-252.

18. Shokeir AA, Hussein AM, Awadalla A, Samy A, Abdelaziz, A, Khater S, Barakat N. Protection against renal ischaemia/reperfusion injury: A comparative experimental study of the effect of ischaemic preconditioning vs. postconditioning. Arab J Urol. 2012; 10(4):418-24.

19. Yang S, Chou WP, Pei L. Effects of propofol on renal ischemia/reperfusion injury in rats. Exp Ther Med. 2013; 6(5):1177-1183.

20. Lin M, Li L, Li L, Pokhrel G, Qi G, Rong R, Zhu T. The protective effect of baicalin against renal ischemiareperfusion injury through inhibition of inflammation and apoptosis. BMC Complementary and Alternative Medicine. 2014; 14:19-27.

21. Weng X, Li S, Song Q, Zhu Q, Song D, Qin Z, Xie Y: Protective effect of nicotinamide adenine dinucleotide phosphate on renal ischemia-reperfusion injury. Kidney Blood Press Res. 2018; 43:651-663.

22. Basile DP, Anderson MD, Sutton TA. Pathophysiology of acute kidney injury. Compr Physiol. 2012; 2(2):1303-53.

23. Ighodaro OM, Akinloye OA. First line defence antioxidants-superoxide dismutase (SOD), catalase (CAT) and glutathione peroxidase (GPX): Their fundamental role in the entire antioxidant defence grid. Alexandria Journal of Medicine. 2018; 54(4): 287-293.

24. Malek M, Nematbakhsh M. Renal ischemia/ reperfusion injury; from pathophysiology to treatment. J Renal Inj Prev. 2015; 4(2):20-27.

25. Khalifa, A, Ghoneim M. Most important cellular changes involved in renal ischemia reperfusion injury and the consequent impact on selected remote organs. Universal Journal of Pharmaceutical Research. 2018; 3(1): 79-87

26. Bonventre JV, Yang L. Cellular pathophysiology of ischemic acute kidney injury. J Clin Invest. 2011; 121(11):4210-4221.

27. Sasaki T, Tsuboi N, Haruhara K, Okabayashi Y, Kanzaki G, Koike K, Kobayashi A,Yamamoto I, Ogura M, Yokoo, T. Bowman capsule volume and related factors in adults with normal renal function. Kidney International Reports. 2018; 3(2), 314-320.

28. Sagiroglu T, Sezer A, Torun N, Yalta T, Yagci MA, Sagiroglu G, Copuroglu E. Protective effect of everolimus on renal ischemia reperfusion injury in rats. Saudi J Kidney Dis Transpl. 2014; 25(2):294-302.
29. Gobe GC, Johnson DW. Distal tubular epithelial cells of the kidney: potential support for proximal tubular cell survival after renal injury. Int J Biochem Cell Biol. 2007; 39:1551-1561.

30. Nørregaard R, Kwon TH, Frøkiær J. Physiology and pathophysiology of cyclooxygenase- 2 and prostaglandin E2 in the kidney. Kidney Res Clin Pract. 2015; 34(4):194-200.

31. Jia Z, Zhang Y, Ding G, Heiney KM, Huang S, Zhang A. Role of COX-2/mPGES-1/prostaglandin E2 cascade in kidney injury. Mediators of Inflammation. 2015; article ID 147894: 1-8

32. Peti-Peterdi J, Harris RC. Macula densa sensing and signaling mechanisms of renin release. J Am Soc Nephrol. 2010; 21(7): 1093-1096.

33. Wang Z, Han Q, Guo Y-L, Liu X-H, Qiu T. Effect of ozone oxidative preconditioning on inflammation and oxidative stress injury in rat model of renal transplantation. Acta Cirurgica Brasileira, 2018; 33(3): 238-249.

34. Gandhi S, Srinivasan BP, Akarte AS. Effective blockade of RAAS by combination of aliskiren and olmesartan improves glucose homeostasis, glomerular filtration rate along with renal variables in streptozotocin induced diabetic rats. Eur J Pharm Sci. 2012; 46:32-42.

35. Bae EH, Kim IJ, Joo SY, Kim EY, Choi JS, Kim CS, Ma SK, Lee JU, Kim SW. Renoprotective effects of the direct renin inhibitor aliskiren on gentamicininduced nephrotoxicity in rats. Journal of the ReninAngiotensin-Aldosterone System. 2014; 15(4): 348-361.

36. Al-Aubaidy H, Saheb HA, Mohammad BI, Hadi NR, Abas SM. Antiatherosclerotic potential of aliskiren: its antioxidant and anti-inflammatory effects in rabbits: a randomized controlled trial. Journal of Pharmaceutical Technology and Drug Research. 2013; 2:11-17.

37. Gonzalez AA, Zamora L, Reyes-Martinez C, SalinasParra N, Roldan N, Cuevas CA, Figueroa S, GonzalezVergara A, Prieto MC. (Pro)renin receptor activation increases profibrotic markers and fibroblast-like phenotype through MAPK-dependent ROS formation in mouse renal collecting duct cells. Clin Exp Pharmacol Physiol. 201744(11):1134-1144.

38. Redza-Dutordoir M, Averill-Bates DA. Activation of apoptosis signalling pathways by reactive oxygen species. Biochimica et Biophysica Acta (BBA) Molecular Cell Research. 2016; 1863(12): 2977-2992

39. Miao J, Wang L, Zhang X, Zhu C, Cui L, Ji H, Liu Y, Wang X. Protective effect of aliskiren in experimental ischemic stroke: up-regulated p-PI3K, p-AKT, Bcl-2 expression, attenuated Bax expression. Neurochem Res. 2016; 41(9):2300-2310. 
الملخص العربى

\title{
تأثير الأليسكرين على إصابة القشرة الكلوية باحتباس الام وإعادة الإرواء فى الجرذان البيضاء: دراسة هستولوجية وهيستوكيميائية مناعية الئه
}

\author{
داليا ابراهيم اسماعيل، الثيماء جمال أبوالخير
}

قسم الهستولوجيا، كلية الطب، جامعة القاهرة، القاهرة، مصر

الخلقية: الإصابة باحتباس الدم و إعادة الإرواء هي السبب الرئيسي لإصابة الكلى الحاد و التي تعتبر أحد المضاعفات الإكلينيكية الثائعة ذات المعدل المرضي المرتفع وتفتقر إلى العلاج الفعال. يعتبر تنشيط نظام رينين- أنجيوتنسين ارتفاع مستوى الأنجيوتنسين II من عوامل الخطر الهامة في إصابة احتباس الدم وإعادة الإرواء. الأليسكرين هو أول مانع مباشرللرينين عن طريق الفم والذي يمنع الخطوة الأولى في نظام رينين- أنجيوتتسين وقد نم اعتماده لعلاج ارتفاع ضغط الدم.

الهرف من العمل: التحقق في ما إذا كان العلاج المسبق بالأليسكرين يحمي القشرة الكلوية لذكور الجرذان البيضاء البالغة التى تعرضت لإصابة احتباس الدم و إعادة الإرو اء. المواد والطرق: تم تقسيم ثلاثين من ذكور الجرذان البيضاء البالغة إلى ب مجمو عات: مجموعة I (المجمو عة الضابطة)، مجموعة II (مجموعة احتباس الدم وإعادة الإرواء)، المجموعة III(مجموعة الأليسكرين): تم معالجة الجرذان بجر عتين من الأليسكرين عن طريق الفم ( . . مج/كجم) قبل إصابة احتباس الدم و إعادة الإرواء، جرعة قبلها بـ ع ساعة وجر عة قبلها بساعة، وتركت لمدة ک ساعة من الإرواء قبل التضحية بها. تم أخذ عينات من الام لتقييم مستويات نيتروجين اليوريا في الدم والكرياتينين وإنزيم ديسميوتاز السوبر أوكسيد في مصل الدم. وصبغت مقاطع الكلي الكلى بصبغات الهيماتوكسيلين و الإيوسين، حمض شيف الأيودى، و الصبغة الهستو كيميائية المناعية ضد إنزيم الأكسدة الحلقى ـ r وكاسباس - r و تلا ذللك تحليل قياسى و إحصائي. النتائج: أظهرت مجمو عة احتباس الدم وإعادة الإرواء تدهورًا في اختبار ات وظائف الكلى مع تغير ات نسيجية هائلة في كريات مالبيجيان الكلوية، و الأنابيب الملتوية. كما كان هناك انخفاض ذو دلالة إحصائية في الكثافة البصرية لتفاعل حض شيف الأيودى، مع زيادة ذات دلالة إحصائية في متوسط نسبة مساحة التعبير المناعي لإنزيم الأكسدة الحلقى ـ Y وكاسباس ـ ؟. أظهرت مجموعة الأليسكرين تحسنا ملحوظا في اختبار ات وظائف الكلى مع الحفاظ علي النسيج الطبيعي للقترة الكلوية. كما كانت هناك زيادة ذات دلالة إحصائية في الكثافة البصرية للتفاعل حمض شيف الأيودى،

مع انخفاض ذو دلالة إحصائية في متوسط نسبة مساحة التعبير المناعي لإنزيم الأكسدة الحلقى ـ ب وكاسباس-؟ّ. الاستتتاج: تم الكثف عن تأثثر وقائي للأليسكرين في تلف القشرة الكلوية الناجم عن احتباس الدم و إعادة الإرواء لاءى ذكور الجرذان البيضاء البالغة. وقد ظهر ذلك في النتائج المعلية والتقييم الهستولوجي و الهستوكيميائي المناعي. 